\title{
Škrinje unutar Zbirke pokućstva Etnografskoga muzeja u Zagrebu - obrada, digitalizacija i mogućnosti
}

Rad se temelji na direktnom iskustvu obrade i digitalizacije škrinja iz Zbirke pokućstva Etnografskoga muzeja u Zagrebu. Prikazani su kvantitativni i kvalitativni podatci (opisi, usporedbe) koji ukazuju na trenutačno stanje škrinja unutar navedene zbirke Muzeja. U radu se navode daljnje mogućnosti za stručnu obradu i valorizaciju te interpretaciju ovih predmeta u budućnosti. Također, rad donosi povijesni razvoj, tipologiju te ulogu i značaj škrinje kao uporabnoga predmeta tradicijske kulture s kraja 19. i početka 20. stoljeća.

Ključne riječi: Etnografski muzej (Zagreb) muzejske zbirke, škrinje, obrada muzejske građe

\section{UVOD}

Jedna od zadaća ${ }^{1}$ koja mi je bila povjerena tijekom stručnoga osposobljavanja (od listopada 2018. do listopada 2019. godine) u Etnografskom muzeju u Zagrebu jest rad na Zbirci pokućstva i kućnoga inventara koju vodi muzejska savjetnica i moja mentorica dr. sc. Zvjezdana Antoš. Među brojnim zanimljivim predmetima u Zbirci pokućstva,

1 Uz rad na zbirci pokućstva i zbirci kućnoga inventara sudjelovala sam u organizaciji i izvođenju muzejskoga hackathona: "Muzejski Hackathon: Hakiraj etnografsku baštinu!" (1.12.2018. - 2.12.2018.), provođenju predavanja "Kakav muzej želite?" (6.4.2019.) i ideacije sa studentima etnologije i kulturne antropologije Filozofskoga fakulteta u Zagrebu s ciljem istraživanja tema i predmeta zanimljivih ispitivanoj skupini u kontekstu osmišljavanja novoga stalnog postava Muzeja, postavljanju izložbi "Sto predmeta za sto godina - Blago Etnografskog muzeja”, “Kapa dolje!' Priča o (ne)pokrivanju glave", koordinirala sam izložbu "Tradicijska oglavlja - Lička kapa i Basket hat" (29.9. - 7.10.2019.), sudjelovala u evakuaciji građe radi izvođenja građevinskih radova te u provođenju pedagoških radionica i vodstva po stalnom postavu Muzeja. 
osobito su mi privukle pozornost škrinje. Naime, Etnografski muzej čuva škrinje različite tipologije i podrijetla te sam stoga, u dogovoru s mentoricom, odlučila svoj rad posvetiti upravo tim predmetima. Rad donosi povijest, razvoj i tipologiju škrinja kao važnih upotrebnih predmeta u tradicijskoj kulturi kraja 19. i početka 20. stoljeća te prikaz stanja škrinja unutar Zbirke pokućstva, ali i iskustvo rada na njihovoj obradi. Navode se smjernice za daljnji rad i istraživanje te se postavlja pitanje budućnosti ovoga muzejskog predmeta i njegove zaštite u kontekstu mogućnosti muzeja.

Korištena literatura prvenstveno su djela etnologinja Vlaste Domaćinović i Branke Vojnović-Traživuk koje se u svojim radovima bave istraživanjem škrinja. Iako izdana davne 1977. godine, knjiga Vlaste Domaćinović "Škrinje od tesanih dasaka u Jugoslaviji”, vrlo sustavno i detaljno obrađuje ovaj tip škrinje te mi je poslužila kao značajan faktografski izvor (Domaćinović 1977.). Jadranski tip škrinja istražuje Branka Vojnović-Traživuk u svojim člancima "Nevjestina škrinja" i "Zbirka škrinja Etnografskog muzeja Split", objavljenim u časopisu Ethnologica Dalmatica (Vojnović 1996., Vojnović-Traživuk 1997.) te katalogu "Lijepe i bogate: škrinje iz Etnografskog muzeja Split" (Vojnović-Traživuk 2010.). Od navedenih radova spomenute autorice, najviše sam se koristila relativno recentno izdanim katalogom (2010.) "Lijepe i bogate: škrinje iz Etnografskog muzeja Split”. Taj mi je katalog, iako korišten i u svrhu komparacije predmeta dvaju muzeja, prvenstveno poslužio kao izvor podataka. Naime, katalog je usmjeren na istraživanje jadranskoga tipa škrinje koji do tada nije bio sustavno i stručno obrađen. Osim navedene literature, kao važni izvori korišteni su i katalozi "Kćeri Maro, sanduk ti je pun" Zvonimira Toldija (Toldi 2008.), "Pokućstvo u Hrvatskoj” Zvjezdane Antoš (Antoš 1988.), "Ljudske škrinje na Goriške" Inge Miklavčeč-Brezigar (Miklavčeč-Brezigar 2000.) te djelo "Kupčinska svadba" Miška Mikulića i Mije Konječića (Mikulić i Konječić 1990.). Nažalost, zbog trenutačne epidemiološke situacije nisam bila u mogućnosti konzultirati literaturu ${ }^{2}$ koju ne posjeduje knjižnica Etnografskoga muzeja i čiji podatci stoga nisi uvršteni u ovaj rad. Elektronički mediji (internet) korišteni su kao izvor općih podataka, a značajnu pomoć i podršku tijekom rada u obliku stručnih savjeta i uputa dobila sam od mentorice dr. sc. Zvjezdane Antoš te kolega mr. sc. Aleksandre Vlatković, dokumentaristice i Domagoja Kačana, restauratora.

\section{POVIJEST I FUNKCIJA ŠKRINJA}

Škrinja je najstariji predmet koji se koristio za spremanje i čuvanje različitih te često, pogotovo imajući na umu same početke nastanka škrinja, vrlo dragocjenih predmeta. Povijesni izvor škrinje kao mjesta pohrane raznovrsnih dragocjenosti može se pratiti od starih civilizacija. Drevni Egipćani su škrinje punili nakitom, zlatom, platnom i brojnim drugim vrijednim te posvećenim predmetima te ih pokapali s pokojnicima kako bi im omogućili da navedene predmete posjeduju i u zagrobnom životu. Također, u Starom se zavjetu navodi zavjetna škrinja kao mjesto čuvanja najveće dragocjenosti - saveza s Bogom (usp. Miklavčić-Brezigar 2000: 17, 23). Na ulogu škrinje kao predmeta u koji su se pohranjivale veoma vrijedne stvari upućuje i njezino ime koje dolazi od latinske

2 Vidi više u: Han 1960./1961. 
riječi scrinium koja označava izduženi okrugli okvir za spremanje papira odnosno važnih dokumenata i zapisa (usp. Miklavčić-Brezigar 2000: 22). Nadalje, upotrebu škrinje kao predmeta za čuvanje važnih dokumenata na području današnje Hrvatske pokazuje i takozvana "Škrinja privilegija" koja je izrađena 1643. godine kao mjesto pohrane najvažnijih državnih dokumenata Kraljevine Dalmacije, Hrvatske i Slavonije (usp. Hrvatska enciklopedija 2020.). Važno je podsjetiti kako su škrinje odnosno sarkofazi služili kao sredstvo ukopa tijekom egipatskoga doba, ali i poslije tijekom antičkoga, koje je u našem području imalo značajniji utjecaj. Tijekom srednjega vijeka škrinje postaju nezamjenjivi dio pokućstva u Europi, a svoj vrhunac u funkcionalnom, ali i umjetničkom smislu doživljavaju u vrijeme renesanse i to osobito tijekom 16. stoljeća. U razdoblju baroka postupno ju zamjenjuju komode, ladičari ili ormari da bi se tijekom 19. stoljeća gotovo i prestale koristiti (usp. Vojnović-Traživuk 2010: 5).

U hrvatskoj tradicijskoj kulturi škrinje su se zadržale cijelim 19. stoljećem i sve do početka 20. stoljeća. Koristile su se kao spremnice za ruho i ostale osobne predmete, no postojale su i velike škrinje koje su služile za spremanje žita. Iako nisu sačuvani konkretni podatci, škrinje su izrađivali uglavnom lokalni majstori. Najčešće je to bilo po narudžbi te su ih prodavali direktno naručitelju ili na sajmovima (usp. Domaćinović 1977: 22). Ovisno o namjeni škrinje (vojnička škrinja, mornarska škrinja, različiti sanduci i dr.) te željama i financijskim mogućnostima naručitelja, škrinje su se manje ili više ukrašavale. Primjerice, mornarska škrinja se oslikavala motivima brodova, čempresa te kraljevskih kruna ili zastava. Uz mornarske, najviše su se ukrašavale škrinje koje su služile za spremanje ruha. One su se ukrašavale rezbarenjem i oslikavanjem, a najčešći motivi bile su stilizirane vaze s cvijećem, čempresi, lišće te različiti geometrijski ornamenti (usp. Antoš 1998: 30).

Osobitu važnost u životu ljudi imale su takozvane svadbene škrinje - škrinje u kojima je mladenka prenosila svoje stvari (miraz, dota) prilikom udaje u mladoženjinu kuću. Te su škrinje imale posebnu ulogu u svadbenim običajima te im se tijekom izrade posvećivala velika pažnja. Osim miraza, one su simbolizirale i zavjet za bogatstvo, oblije, sreću i plodnost u novom bračnom životu (usp. Vojnović-Traživuk 2010: 10). Na području Hrvatske nalazimo niz različitih običaja vezanih uz svadbenu škrinju. Ona se uglavnom prevozila nekoliko dana prije svadbe i to javno u obliku vesele svadbene povorke. Međutim, ovisno o području, katkad se odvozila i tajno (Buzeština tzv. odvoz banjka) jer je postojao običaj da seoski momci nastoje pregraditi put pri prijevozu i ukrasti nešto s kola za što su poslije tražili otkup (usp. Vojnović 1997: 29, prema Mikac 1977.). U Orebiću i na otoku Korčuli, uz pjesmu, ples i čašćenje, škrinju su prenosila četiri mladića, ali se ona pritom nije smjela spustiti na tlo sve dok ne bi došli do mladoženjine kuće (usp. Vojnović 1997: 29, prema Fisković 1971.). Vesela svadbena povorka zabilježena je i u Prigorju, pa su tako u Kupčini postojali škrinjari koji su zajedno s mladencima, u svečanoj paradi na kolima, išli po mladenkinu svadbenu opremu, dotu koju su činile škrinje, krevet, ormar itd. (usp. Mikulić i Konječić 1990: 38). Svadbena škrinja (sanduk) zabilježena je i u pjesmama koje su se pjevale pri selidbi djevojačkoga ruha. U Slavoniji su djevojke od majki nasljeđivale "djevojački sanduk" te se pri njegovu prijevozu u mladoženjinu kuću pjevalo: 
"Sandučići pozvekuju malo, nepuno,

Mara moli milu majku, da ga napuni,

Mila majka miloj Mari milo govori:

'Ne brini se kćeri Maro, sanduk ti je pun."'3

\section{STANJE I SMJEŠTAJ ŠKRINJA}

Tijekom stručnoga osposobljavanja u Etnografskom muzeju, osim rada na zbirci, povjerena mi je i zadaća obrade te digitalizacije muzejske građe iz zbirki kućni inventar i pokućstvo. Proces digitalizacije u računalnom (muzejskom) programu Modulor provodio se na temelju fizičke obrade predmeta $u$ depoima pri čemu je moj osnovni zadatak bio evidentiranje, mjerenje i fotodokumentacija predmeta. Usporedno s radom u depou, evidentirani predmeti s pripadajućim fotografijama upisivani su u Modulor (ako zapis i fotografija predmeta već nisu postojali) prema inventarnim karticama Muzeja.

Zbirka pokućstva prema ispisu ${ }^{4}$ podataka iz dokumentacijskoga sustava Modulor broji 633 predmeta. Riječ je o predmetima koji sačinjavaju osnovno uređenje doma kao što su kreveti, ormari, stolovi, komode, kredenci, ogledala, kolijevke te pojedini neuobičajeni primjerci kao što je stroj za pranje rublja (preteča današnje perilice rublja) ili spremnik za led (preteča zamrzivača). Značajan dio ove zbirke, ukupno 149 predmeta, čine škrinje.

Pod pojmom škrinja u ovome se radu podrazumijevaju svi predmeti koji imaju istu funkciju bez obzira na naziv pod kojim su predmeti zavedeni u dokumentacijskim karticama i Modulor-u. Tako su, osim škrinja, u ovaj pregled uključeni i predmeti zavedeni pod nazivima ${ }^{5}$ kao što su kovčeg i sanduk, a jasno je iz opisa predmeta da svojom formom i funkcijom pripadaju škrinjama te da je riječ samo o drugom nazivu. Tijekom rada na zbirci pokućstva ukupno sam evidentirala, izmjerila i fotodokumentirala 149 škrinja. Od navedenoga broja evidentiranih predmeta bez inventarne oznake (BB) njih je 17. Potrebno je naglasiti kako je bilo vrlo teško, budući da se zbirka nalazi u fazi obrade i pripreme za registraciju, dobiti točan uvid u zbirku. Naime, tijekom vremena došlo je do gubitka ili brisanja inventarnih brojeva sa samoga predmeta što je dodatno otežalo točno dokumentiranje i obradu građe, za što je potrebna daljnja ekspertiza voditeljice zbirke. Osim navedene, druga otegotna okolnost kod škrinja, kao i ostalih voluminoznih predmeta unutar zbirke pokućstva i drugih muzejskih zbirki, jest nedostatak odgovarajućega prostora za smještaj. Škrinje se u Etnografskom muzeju čuvaju u dvama depoima, a pojedini primjerci su izloženi u stalnom postavu. Jedan je depo na petome katu, a drugi se nalazi u podrumskom prostoru Muzeja. U obje čuvaonice škrinje su smještene tako da se, poštujući osnove čuvanja muzejske građe,

3 Stihovi narodne pjesme koju je zabilježio Luka Ilić Oriovačanin pišući o slavonskim svadbenim običajima (Toldi 2008: 3).

4 Podatci su preuzeti iz dokumentacijskoga sustava Modulor dana 21. veljače 2020.

5 Problem nazivlja predmeta u svrhu dobivanja što realnijeg prikaza i mogućnosti obrade zbirki otvara pitanje izrade tezaurusa. Vidi više u: Križaj 2017. i Kolbas 2006. 
maksimalno iskoristi sav dostupan prostor. Radi toga, pojedini su primjerci bili potpuno nedostupni. Škrinje koje se nalaze u depou na petome katu muzeja bile su zahvalnije za obradu jer su bile dostupne. Usporedno sa stručnim osposobljavanjem i radom na zbirci odvijala se i evakuacija građe radi izvođenja građevinskih radova u sklopu obnove pročelja i pripreme za unutrašnju obnovu muzeja te je iskorištena situacija kako bi se ovu građu adekvatno dokumentiralo. ${ }^{6}$ Isti slučaj, nažalost, nije bio sa škrinjama koje su smještene u podrumskom prostoru muzeja i koje čine veći dio čitavoga fundusa škrinja Zbirke pokućstva. Tako u većini slučajeva u podrumskom depou, radi njihove nedostupnosti, nije bilo moguće u potpunosti sagledati pojedine i najveće predmete pa se fotografiranje predmeta pokazalo kao pravi izazov. Otežan pristup i mali razmak među predmetima rezultirali su, nažalost, nekvalitetnim fotografijama koje mogu imati samo inventarizacijsku ulogu i poslužiti kao pomoćna dokumentacija. Također, treba naglasiti i kako je često u radu na dokumentaciji škrinja, osim kolege, akademskoga kipara Domagoja Kačana, restauratora zaduženoga za Zbirku, bilo potrebno uključiti u rad i tehničara radi težine i (ne)dostupnosti predmeta. Škrinje su, ovisno o materijalu (vrsti drveta), starosti, kvaliteti izrade te načinu čuvanja tijekom vremena u različitim stanjima očuvanosti - od škrinja koje su vrlo dobro očuvane i na kojima su provedeni restauratorski zahvati do onih koje je potrebno restaurirati i konzervirati. S obzirom na kompleksnost problema, neadekvatnoga smještaja i mogućnosti za daljnjom obradom građe, preseljenje u nove prostore ${ }^{7}$ omogućit će primjereno pohranjivanje, zaštitu i predstojeće restauratorske radove. Ovaj rad stoga ima za cilj prikazati škrinje u okviru Zbirke pokućstva te će doprinijeti njihovoj daljnjoj stručnoj valorizaciji i interpretaciji u budućnosti.

\section{TIPOLOGIJA ŠKRINJA}

Škrinje koje se čuvaju u Etnografskom muzeju različitih su oblika (tipologije) te mjesta i vremena nastanka. Neovisno o njihovoj funkciji, oblikom se škrinje može podijeliti na tri tipa - škrinje od tesanih dasaka (kobilaši te škrinje s lagano nakošenim ili ravnim poklopcem), jadranski te dinarski tip škrinje (usp. Vojnović-Traživuk 2010: 6).

Škrinje od tesanih dasaka karakterizira poseban način konstrukcije pri čemu su pojedini dijelovi sastavljeni ukladanjem dasaka u noge i drvenim klinovima bez korištenja ljepila ili željeza (usp. Domaćinović 1977: 10). Unutar ovoga tipa razlikuju se škrinje s kosim poklopcem i bez rogova na uglovima, karakteristične za prostor Posavine, Moslavine i Podravine te škrinje s kosim poklopcem i rogovima na uglovima karakteristične za prostor Slavonije (usp. Antoš 1998: 33). Tip škrinje s kosim poklopcem i rogovima na uglovima naziva se još i kobilaš, kobilan. Škrinje od tesanih dasaka mogu imati i ravan krov, a ovaj se tip uglavnom koristio u zapadnom dijelu zemlje i u Istri. Većinom se ukrašavao poklopac i prednja stanica dok su bočne strane rijetko bile ukrašene. Ukrasi

6 Valja naglasiti kako se, iako su predmet na petome katu bili fizički dostupni, fotografska se dokumentacija tu, kao i u depou u podrumu, odvijala bez odgovarajuće rasvjete i kamerom mobilnoga uređaja.

$7 \quad$ Etnografski muzej provodi projekt "Rekonstrukcija objekta napuštene zgrade Zemaljske uzorite pivnice u Kačićevoj ulici" kako bi se stvorili prostori za muzejske čuvaonice, interaktivan depo i radionice koje će se staviti u funkciju do 2023. godine. Više: http://www.emz.hr/Projekti/Projekt\%20obnove\%20muzeja (pristup 1. svibnja 2020.). 
su geometrijski uparene ravne horizontalne i vertikalne, kose i cik-cak linije te različite kružnice i rozete (usp. Domaćinović 1977: 18-24). Domaćinović navodi kako su majstori (škrinjari) isporučivali škrinje direktno u ruke korisnika, najčešće naručitelja, te zbog toga "one nikad nisu postale bezličnim predmetom prometa....već je svaka škrinja za sebe unikat i nosi na sebi trag ličnosti proizvođača." (Domaćinović 1977: 22).

Jadranski tip škrinje podrazumijeva škrinje čije su plohe oblikovane od cjelovitih komada drva, a spojene su međusobnim nadopunjavanjem zubaca bočnih stranica, tzv. vez na pero ili lastin rep. Poklopci ovih škrinja su ravni, a nogari niski u obliku stiliziranih lavljih šapa. Jadranski tip škrinje koristio se na području južne Hrvatske odnosno duž čitave jadranske obale. Prednja ploha tog tipa škrinje većinom je ukrašena rezbarenjem, a katkad i oslikavanjem, pri čemu su osnovni dekorativni oblici motivi cvijeća, vaza, ptica, čempresa te raznovrsni geometrijski ornamenti (usp. Vojnović-Traživuk 1995/1996: 28). Zrcalna simetrija motiva kompozicije ukazuje da su najvjerojatnije postojale tzv. šablone koje su drvodjelci i drvorezbari koristili za njihovu izradu. One najbogatije oslikavali su slikari, no većina njih je obojana u drvodjeljskim radionicama gdje su pojedini majstori bili zaduženi za bojanje (usp. Vojnović-Traživuk 2010: 34-35).

Dinarski tip škrinje, sanduk ili kovčeg, kvadratnoga je oblika s poklopcem i stranicama spojenim metalnim čavlima. Ovaj tip škrinje nema nogara, a prednja je stanica ukrašena rezbarenim geometrijskim i biljnim motivima. Dinarski tip škrinje nalazimo, kao što samo ime sugerira, na dinarskom području odnosno jugoistočnom dijelu Hrvatske te u Bosni, Hercegovini i Crnoj Gori (usp. Vojnović-Traživuk 2010: 7-9).

Većina predmeta Muzeja potječe s prostora Hrvatske s iznimkom nekolicine predmeta iz Bosne i Hercegovine (5 predmeta), Kosova ( 2 predmeta), Albanije (2 predmeta) i Crne Gore (1 predmet). Prema datacijama na inventarnim karticama, škrinje koje se čuvaju u Muzeju izrađene su od sredine 19. do prve polovice 20. stoljeća, a podatci o njihovu autoru (majstoru, škrinjaru ili drvodjeljskoj radionici), osim kod dvaju predmeta, nažalost nisu sačuvani odnosno zabilježeni. Nabava škrinja, bilo otkupom ili u obliku dara, započela je gotovo odmah po osnutku muzeja i traje do današnjih dana. ${ }^{8}$ Ipak, većina predmeta je nabavljena do devedesetih godina prošloga stoljeća i to nabavom od privatnih osoba. Očekivano najzastupljeniji tip škrinja, s obzirom na to da su se izrađivale na području Posavine i Hrvatskoga zagorja odnosno okolice Zagreba, su škrinje od tesanih dasaka. Riječ je o 72 predmeta $^{9}$ različite starosti, podrijetla i podtipova (kobilaši, kobilani škrinje s ravnim ili kosim krovom bez uški) te različiti prijelazni oblici i varijante tih podtipova. Škrinje od tesanih dasaka izrađivale su se na širokom prostoru od istoka (Slavonije i Baranje) preko centralnoga dijela (Podravine i Moslavine) pa sve do zapadnoga i sjevernoga dijela današnje Hrvatske. Primjerci tih škrinja koji se danas čuvaju u Etnografskom muzeju potvrđuju široku rasprostranjenost ovoga tipa škrinja. Tako su pojedini primjerci nabavljeni iz Hrvatskoga zagorja (Stubički Laz - EMZ 8452, Razvor - EMZ 16249 i dr.), Podravine (Koprivnica - EMZ 18527,

$8 \quad$ Predmet zaveden u inventarnu knjigu s najnižom inventarnom oznakom (EMZ 594) nabavljen je 1921. godine ,a s najvišom (EMZ 47240) 2008. godine.

9 U navedeni broj nisu uključeni oni predmeti koje je zbog nedostataka fotografske dokumentacije, podataka ili nedefiniranih opisnih podataka nemoguće tipološki odrediti. 
Torčec - EMZ 4527, i dr.), Posavine (Gornja Letina - EMZ 22715 i dr.), okolice Zagreba (Remete - EMZ 21376, Remetinec - EMZ 24249 i dr.) te Slavonije (Viljevo Donje - EMZ 634 i dr.) i Istre (Markovac (Višnjan) - EMZ 14988). Osim s područja Hrvatske sačuvane su i dvije škrinje od tesanih dasaka s Kosova koje se ističu, u odnosu na druge škrinje, različitom (bojanom) dekoracijom.

Najveći broj škrinja od tesanih dasaka u Muzeju su one s ravnim ili kosim krovom bez uški. Riječ je o škrinjama karakterističnim za područje sjeverne Hrvatske (Posavina, Podravina, Moslavina te Hrvatsko zagorje). Te škrinje su dekorirane plitko izvedenim geometrijskim motivima - ravnim, vertikalnim, kosim i cik-cak linijama te kružnicama i rozetama. Katkad su se škrinje ukrašavale bojanjem te oslikavanjem. Tako na području Slavonije i Baranje postoje škrinje na kojima su ukrasni motivi kružnica i rozeta obojeni u dvije boje (Antoš 1998: 33). Oslikane škrinje, kao što je škrinja iz Turopolja (EMZ 26684), vrlo su rijetke (Sl. 1). Također, veliki broj predmeta nije ukrašavan ili je dekoriran samo poklopac škrinje i to jednostavno kosim linijama koje se preklapaju. Iznimku predstavlja samo nekolicina primjeraka izrađenih u Slavoniji s dublje izvedenom ornamentikom sličnoj onoj na kobilašima, najučestalijim podtipom škrinje od tesanih dasaka na tom području. Utjecaj lokaliteta proizvodnje s određenom tradicijom izrade škrinja vidljiv je i na predmetima iz Hrvatskoga zagorja. Naime, gotovo sve škrinje koje prema lokalitetu proizvodnje pripadaju Hrvatskom zagorju su ukrašene, a nekim su predmetima čak i stranice ispunjene ornamentikom. U Hrvatskom zagorju, osobito na području Kraševeca (Ivanec) u blizini Lepoglave, izrada škrinja od tesanih dasaka bila je vrlo razvijena i dosta dugo se zadržala što potvrđuje i činjenica kako su seljaci zagrebačke okolice (Resnik, Donja Greda) nabavljali svoje škrinje na sajmu u Ivancu (usp. Domaćinović 1977: 29). Iz Kraševca (Ivanca) u Etnografskom se muzeju čuvaju tri škrinje. Jedna nabavljena 1920. godine, a izrađena u drugoj polovici 19. stoljeća za koju se kao autora navodi Vinka Kraša (EMZ 1085) te dvije koje su izrađene početkom 20. stoljeća, a nabavljene istovremeno u Ivancu 1970. godine (EMZ 23143 i EMZ 23150). Domaćinović na temelju vlastitih istraživanja navodi kako su sredinom 20. stoljeća u Ivancu još uvijek postojala tri škrinjara - Vinko Kraš, Videc Ćiril (Kraš) te Šlivarev Maler (usp. Domaćinović 1977: 49). Zanimljiv je podatak kako je jedna od dviju škrinja otkupljena 1970. godine iz Ivanca, otkupljena upravo od Ćirila Kraša. S obzirom na navedeno, postoji mogućnost da je tu škrinju, iako u inventarnoj kartici nije zaveden kao autor, izradio upravo Ćiril Kraš koji je jedan od posljednjih škrinjara. Škrinja (Sl. 2) je ukrašena gustim raspoređenim i detaljno razrađenim motivima (trokut, list) što ukazuje na mlađe podrijetlo predmeta (usp. Domaćinović 1977: 24).

Za područje Slavonije, kao što je već navedeno, karakteristične su škrinje pod nazivom kobilaš ili kobilan. U Modulor-u je kao vrsta/naziv kobilaš, kobilan, kobilaš, mali cifrani i kobilaš uška zavedeno 17 predmeta. ${ }^{10} \mathrm{Uz}$ veliki broj škrinja koje potječu iz Posavine, ${ }^{11}$ značajan broj predmeta izrađen je u Slavoniji i Baranji (Prkovci - EMZ 20127, Branjin Vrh - EMZ 19951, Slavonski Šamac - EMZ 5159 i dr.), a riječ je uglavnom o kobilašima.

$10 \mathrm{U}$ Moduloru su upisani nazivi preuzeti s inventarnih kartica.

11 Povećan broj predmeta s navedenoga područja rezultat je činjenice da su isti zaplijenjeni Hansu Georgu Bienu i potom uvršteni u fundus Muzeja. 
Kobilaši su ujedno i najdekorativniji tip škrinja od tesanih dasaka. Svaki kobilaš na sebi ima više ili manje bogate duboko urezane geometrijske ornamente (Sl. 3).

Jadranski tip škrinje u zbirci pokućstva zastupljen je s 11 predmeta. Ovaj tip škrinje koristio se duž čitave obale Jadrana tako da se u zbirci čuvaju predmeti korišteni i nastali u Kotoru, Čilipima, Lumbardi, Benkovcu, Primorju te na Lošinju. Riječ je o veoma zanimljivim primjercima na kojima je vidljiva bogata dekoracija prednje plohe karakteristična za taj tip škrinje. Ukrašene su motivima stiliziranih vaza s cvijećem, lišćem, čempresima, pticama, hramovima te različitim geometrijskim ornamentima. U komparaciji s predmetima sačuvanima u Etnografskom muzeju Split uočava se da je riječ o veoma sličnim primjercima rađenim pomoću šablona, kao što je već bilo spomenuto, koje su se onda mijenjale i prilagođavale tijekom vremena i od radionice do radionice. Tako je kod predmeta EMZ 16954 (Sl. 4) i 630:SLT;2479 riječ o gotovo identično dekoriranoj prednjici škrinje. Obje škrinje su iz Boke kotorske (630:SLT;2479) odnosno Kotora (EMZ 16954), a razlikuju se u elaboriranosti samoga prikaza. Središnji motiv četverostranoga okvira ispunjenoga trokutićima je trbušasta vaza s cvjetovima (usp. Vojnović-Traživuk 2010: 98). U slučaju škrinje iz splitskoga muzeja, riječ je o vazi s trinaest cvjetova dok je kod zagrebačkog predmeta riječ o njih jedanaest. Sa svake strane gornjega dijela buketa škrinje imaju po jednu pticu, a na predmetu iz splitskog muzeja ptice su obojene crvenom i oker žutom bojom. Slična se situacija ponavlja i na bočnim zrcalno simetričnim motivima. Riječ je o istoj kompoziciji, ali s manje jasnom i manje detaljnom izradom na predmetu iz Etnografskoga muzeja u Zagrebu. Između dvije škrinje, značajnija razlika je u broju izvedenih ptica kojih je na zagrebačkoj škrinji osam, a na splitskoj dvanaest. Ovdje je vjerojatno riječ o pojednostavnjivanju predloška jer je motiv ptice zahtijevao visoku tehniku izrade i vještinu koja je vidljiva na splitskom, ali nedostaje na zagrebačkom predmetu.

Na škrinjama jadranskoga tipa koji podrazumijeva ravni poklopac i stilizirane noge u obliku lavljih šapa, rijetko se ukrašavala i unutrašnjost poklopca na čijoj se sredini stavljalo ogledalo, a sa svake strane ogledala vaze s cvijećem i pticama. ${ }^{12}$ Jedna takva škrinja čuva se u Etnografskom muzeju u Zagrebu i dio je njegova stalnoga postava. Motivi vaze s cvijećem, ptice, čempresi te hramovi interpretiraju se kao simboli svadbe, djevojke-mladenke, novoga života i plodnosti odnosno upućuju da je riječ o škrinji za nevjestu13 (usp. Antoš 1998: 30).

Dinarski tip škrinje brojčano je najmanje zastupljeni tip škrinje u zbirci pokućstva Etnografskoga muzeja te postoji samo jedan primjerak. Škrinja ili čekmeta (EMZ 13461), kako je upisana u Modulor, izrađena je u Mostaru i predstavlja tipičan primjerak ovoga tipa škrinja. Naime, škrinja je bez nogara, manjih je dimenzija te dekorirane prednje stranice rezbarenim geometrijskim i biljnim oblicima.

Izuzev ova tri osnovna tipa škrinja u zbirci se čuvaju i brojne druge varijante i podtipovi škrinja kao što su dvije pomorske škrinje. Pomorske škrinje konstrukcijski su

12 Vojnović-Traživuk ove škrinje smatra podtipom jadranskih te ih naziva dalmatinskim škrinjama, a sačuvano je samo 6 cjelovitih primjeraka. (usp.Vojnović-Traživuk 2010: 29).

13 O simbolici ornamentike više u: Bruck-Auffenberg 1912., Vojnović-Traživuk 2010. i Ban 2017. 
istovjetne jadranskom tipu, ali su obično manjih dimenzija i karakteristične dekoracije različite od jadranskoga tipa škrinja. Naime, pomorske škrinje obično se prepoznaju po karakterističnom obliku s prednje i unutrašnje strane poklopca. Najčešće se pojavljuju motivi brodova, čempresa, kraljevskih kruna ili zastava što potvrđuje i predmet EMZ 15175 (Sl. 5). Navedeni simboli ukazuju na državu za koju pomorac ili njegov brod plovi. Nažalost, u inventarnoj kartici nema detaljnijih podataka o nastanku same škrinje ili o njezinu vlasniku. Osim pomorskih škrinja u zbirci se čuvaju i drvene škrinje/ sanduci trapezoidnih stranica i ravnoga poklopca koji često znaju biti okovani - sanduk okovanec $^{14}$ kao što je to predmet EMZ 22740. Veoma su zanimljive i obojene škrinje - maljani sanduci. Ti maljani sanduci imaju ravni poklopac te nemaju nogu, a stranice su im zupčasto spojene na pero. Najčešće su obojeni (bojadisanje) u jednu tamniju boju (plavu, crvenu, smeđu i dr.) na koju su onda maljani svjetlijim bojama stilizirani biljni ornamenti. Taj oblik škrinje najčešće je evidentiran na području Slavonije (od kuda su i dva maljana sanduka Etnografskoga muzeja - EMZ 11315 i EMZ 12879), no predstavljaju kulturno dobro širega, alpskoga i panonskoga, područja. Naime, sanduci ukrašeni bojanjem kupovani su na sajmovima na koje su ih donosili majstori iz Zagorja, Slovenije i Austrije (usp. Toldi 2008: 5). Pripadanje istom kulturno-trgovačkom krugu vidljivo je i u miješanju različitih utjecaja u izradi i oblikovanju škrinja. S obzirom na područje na kojem nastaju, kvaliteti izrade i poznavanju različitih konstrukcijskih tipova, dolazi i do izrade pojedinih netipičnih primjeraka. Tako se u zbirci pokućstva čuva škrinja iz Gospića (EMZ 25392) koja konstrukcijski (vez na pero) odgovara jadranskom tipu. Ta je škrinja, kao i jadranska škrinja, postavljena na noge, ali ne u obliku lavljih šapa, već je ovdje riječ o običnim daskama. Među ostalim, prednja ploha nije dekorirana, a poklopac je sastavljen od dviju dasaka. Potrebno je uzeti u obzir i kako je na izgled i izradu škrinje uvelike utjecalo i bogatstvo područja i obitelji koja škrinju naručuje ili kupuje te o vremenu kada je nastala. Izrada se škrinja mijenja tijekom vremena s razvojem i promjenom životnih prilika. Na pojedinim se primjerima stoga može uočiti promjena u konstrukciji škrinje te one više podsjeća na formu komode ili ladice koje postupno istiskuju škrinju iz upotrebe i preuzimaju njezinu funkciju.

\section{REZULTATI I DALJNJE MOGUĆNOSTI}

Tijekom rada na obradi škrinja evidentirano je 149 predmeta. Nekim predmetima, već obrađenim u digitalnom obliku, pridodana je samo pripadajuća fotodokumentacija, a novi digitalni zapis stvoren je predmetima koji nisu na ovaj način dokumentirani. Nažalost, zbog mnogih drugih zaduženja koje, uz posao vođenja zbirki, obavlja kustos te zbog građevinskih radova koji su u velikoj mjeri utjecali na organizaciju rada u Muzeju, za vrijeme trajanja stručnoga osposobljavanja nisam bila u mogućnosti s mentoricom krenuti u daljnju fazu obrade škrinja unutar Zbirke pokućstva. Upravo je zbog toga netaknuta ostala problematika predmeta bez inventarne oznake (BB). Predmetima bez evidentirane inventarne oznake potrebno je utvrditi je li predmet inventiran, a inventarni broj izgubljen/izmijenjen te pripada li inventarni broj nepronađenih predmeta

14 Lokalni naziv je zabilježen na jednoj inventarnoj kartici. 
predmetima koji su u depoima, a nemaju inventarne oznake. Riječ je dakle o zahtjevnom procesu koji traži veliku pozornost i koordiniranost te ekspertizu voditelja zbirke. Iako se danas škrinje ne izrađuju, a sve manje i koriste u suvremenom stanovanju te su relativno dobro obrađene (Domaćinović - škrinje od tesanih dasaka, Vojnović-Traživuk - jadranski tip) istraživanje je uvijek važno, usudim se reći i potrebno, kako bi se što detaljnije te $u$ kontekstu sadašnjega vremena i potreba prikazali te razumjeli muzejski predmeti. U okviru razmatranja o budućnosti ovih predmeta nemoguće se ne osvrnuti na pitanje odgovarajuće pohrane i čuvanja ovih predmeta. Prethodno sam već spomenula voluminoznost predmeta kao osnovni problem u adekvatnom zbrinjavanju i zaštiti. Vjerujem kako problem većine muzeja predstavlja upravo nedostatak prostora za čuvanje građe prema pravilima struke što je najvidljivije upravo kod predmeta većih dimenzija i težina. Etnografski muzej tu nije iznimka. Unatoč maksimalnom pridržavanju temeljnih principa zaštite muzeološke građe (osiguravanje mikroklimatskih uvjeta, zaštita od bioloških nametnika i sl.), predmeti su smješteni u dvama međusobno razdvojenim depoima (na petome katu i u podrumskom prostoru) te su na malom prostoru i gotovo su položeni jedan na drugome. Potrebno je napomenuti i kako je svaki postupak konzervacije te restauracije, zbog otežanoga pristupa i transporta predmeta do restauratorskih radionica, vrlo zahtjevan, a za neke primjerke gotovo i nemoguć. Ipak, novi prostori čuvaonica i depoa, predviđeni već započetim projektom, ${ }^{15}$ riješit će spomenute probleme te omogućiti adekvatnu zaštitu predmeta, osigurati uvjete za daljnje istraživanje i tako uvelike olakšati rad na zbirci.

U izložbenom smislu škrinje imaju velik potencijal - izuzev vlastite veličine kao otežavajuće okolnosti u pogledu transporta i tehničke realizacije izvedbe. Osim za potrebe preglednih ili komparativnih izložbi škrinja ili pokućstva, ovi se predmeti mogu izlagati u kontekstu brojne druge tematike. Kao što je prije izloženo, škrinje su imale značajnu ulogu u svadbenim običajima 19. i početka 20. stoljeća. Svadbena škrinja i predmeti u njoj bili su miraz koji je nevjesta donosila u brak. Međutim, i uz ove konkretne vrijednosti, škrinja je imala i one simboličke. Simbolizirala je zavjet za bogatstvo, obilje, plodnost i sreću u bračnom životu te se kao simbol određenih vrijednosti i želja može promatrati i u sadašnjem vremenu i kroz usporedbu s današnjim statusnim simbolima. Također, navedeni predmeti mogu naći i nalaze ${ }^{16}$ svoje mjesto u kontekstu izložbi uvijek aktualnih tematika kao što su svadbeni običaji i bračni život te danas vrlo moderne teme unutarnjega uređenja doma. Škrinja predstavlja osobni predmet što se vidi na primjeru svadbene škrinje. Uzmemo li konkretno svadbenu škrinju vidimo da je ona intimni predmet mlade djevojke/žene (gotovo kao što je ženska torbica) u kojoj donosi, tj. prenosi sve svoje važne te vrijedne stvari. Moguće je škrinju staviti i prikazati u paraleli s kovčegom i s putovanjem jer je selidba u mladoženjinu kuću vjerojatno i jedino "putovanje" na koje se jedna djevojka sa sela tijekom svoga života uputila i za koje se spremila. Ujedno, ne treba zanemariti potencijal škrinje kao primjera tehničke vještine (rukotvorine) obrade drva kao što je bilo i prikazano na izložbi "Drvo u tradicijskoj obradi" postavljenoj u Muzeju 1974. godine. Dakle, mogućnost upotrebe i iskoristivost

15 Vidi bilješku 7.

16 Primjerice na izložbama: "Mladenka u hrvatskim svadbenim tradicijama" (27.6. - 29.9.1996.) te "Pokućstvo u Hrvatskoj - etnološki pogled na unutrašnje uređenje doma" (10.9.1998. - 25.10.1998.). 
ovoga predmeta u izložbene svrhe različitih interdisciplinarnih tema uistinu je velika te bi uz promišljen dizajn i izvedbu, škrinja zasigurno predstavljala zanimljiv izložak široj publici koju bi se tako, posredno, podsjetilo i podučilo o minulim vremenima.

\section{ZAKLJUČAK}

Tijekom rada na Zbirci pokućstva obrađeno je (evidentirano, izmjereno i fotodokumentirano) 149 škrinja. Neevidentirani podatci (najčešće fotografije) uključeni su u digitalni dokument računalnoga sustava Modulor ili je on načinjen ako do tada u depou evidentirani predmet nije bio digitaliziran. Upotpunjavanje podataka i digitalizacija predmeta jedan je od osnovnih uvjeta funkcioniranja i razvoja Muzeja u današnjem digitalnom dobu te je stoga i prijeko potreban.

Praktični rad s muzejskom građom rezultirao je dragocjenim uvidom i iskustvom rada na zbirci što je jedan od temeljnih poslova kustosa. Među ostalim, otvorila su se pitanja vezana za daljnji proces rada na zbirci, odnosno muzeološku obradu i istraživanje, što je potaknulo moje zanimanje i poticaj za vlastiti rad te stručno usavršavanje.

Može se zaključiti kako su se škrinje kao predmeti pokazale vrlo zanimljivim i višeznačnim objektima s velikim potencijalom za istraživanje i prezentaciju u širem, interdisciplinarnomu kontekstu.

\section{LITERATURA I IZVORI:}

ANTOŠ, Zvjezdana. 1998. Pokućstvo u Hrvatskoj. Zagreb: Etnografski muzej.

BRUCK-AUFFENBERG, Natalija. 1912. Dalmacija i njena narodna umjetnost. Uzorci (šare) $i$ starinske umjetničke tehnike, upotrebljavane negda u narodu i Crkvi: čipke, vezovi, ćilimske tkanine, nakit, narodna nošnja i druge stvari, koje Dalmatinci nose i izradjuju. Beč: Anton Schroll\&Co.

DOMAĆINOVIĆ, Vlasta. 1977. Škrinje od tesanih dasaka u Jugoslaviji. Vinkovci: Općina Vinkovci.

HAN, Verena. 1960/1961. Umjetnička škrinja u Jugoslaviji od XIII. do XX. stoljeća. Beograd. Muzej primenjene umetnosti.

KOLBAS, Irena, 2006. “Tezaurus etnologije ali kulturne antropologije”. Etnološka istraživanja 11: 95-101.

KRIŽAJ, Lana. 2017. Tezaurus spomeničkih vrsta: Podatkovni standardi u inventarima graditeljske baštine. Zagreb: Mala biblioteka Godišnjaka zaštite spomenika kulture Hrvatske.

MIKLAVČIĆ-BREZIGAR, Inga. 2000. Ljudske škrinje na Goriškem. Nova Gorica: Goriški muzej.

MIKULIĆ, Miško i Mijo KONJEČIĆ. 1990. Kupčinska svadba. Donja Kupčina: Zavičajni muzej Donja Kupčina.

TOLDI, Zvonimir. 2008. Kćeri Maro, sanduk tije pun. Slavonski Brod: Muzej Brodskog Posavlja. VOJNOVIĆ, Branka. 1995/1996. “Nevjestina škrinja”. Ethnologica Dalmatica 4-5: 27-35. 
VOJNOVIĆ-TRAŽIVUK, Branka. 1997. “Zbirka škrinja Etnografskog muzeja Split”. Ethnologica Dalmatica 6: 117-145.

VOJNOVIĆ-TRAŽIVUK, Branka. 2010. Lijepe i bogate: Škrinje iz etnografskog muzeja Split. Split: Etnografski muzej.

"Hrvatski državni arhiv" Hrvatska enciklopedija, mrežno izdanje, 2020. < http://www. enciklopedija.hr/Natuknica.aspx?ID=26439>. (pristup 1.5.2020.). 